\title{
THE CONTINUAL IMPROVEMENT IN THE CERTIFICATION OF COFFEE FARMS: A CASE STUDY
}

\author{
Claúdio Vieira Castroํㅗ Jean Marcel Sousa Lira², Eduardo Gomes Salgado³, \\ Luiz Alberto Beijo ${ }^{4}$
}

(Received: July 19, 2018; accepted: September 10, 2018)

\begin{abstract}
The certification of agricultural products is considered a strategy that promotes sustainability and appreciation of product. In coffee production, the Certifica Minas Café is the only public coffee certification program in Brazil. However, over the years, many coffee farms that have this certification reduce their competence to meet the requirements, stabilizing at minimum levels of compliance, which allows maintaining the certificates, but does not promote continual improvement. Therefore, this study aimed to evaluate the effect of Certifica Minas Café certification on the improvement of sustainability over time on coffee farms. For this, a case study with two properties in the south of the state of Minas Gerais was carried out in which one of them quest to not achieve continuous improvement, while the other does. On the coffee farm of the first case was observed a reduction of number of requested fulfilled by the certification program over time. While coffee farm of the second case there was a reduction in investment and low concern to maintain the requirements established by the certification. Lastly, this paper hypothesizes that improvement of sustainability depends on understanding the benefits of certification in the long term and is related to a behaviour change by the certified farm.
\end{abstract}

Index terms: Certifica Minas Café, improvement of sustainability, coffee production.

\section{A MELHORIA CONTÍNUA NA CERTIFICAÇÃO DAS FAZENDAS DE CAFÉ: UM ESTUDO DE CASO NO SUL DE MINAS GERAIS}

RESUMO: A certificação de produtos agrícolas é considerada uma estratégia que promove a sustentabilidade e a valorização do produto. Na produção de café, o Certifica Minas Café é o único programa público de certificação de café no Brasil. No entanto, ao longo dos anos, muitas fazendas de café que possuem esta certificação deixam de atender vários dos requisitos reduzindo o nível de conformidade, o que as permite manter a certificação, porém não promove uma melhoria contínua. Portanto, este estudo teve como objetivo avaliar o efeito da certificação Certifica Minas Café na melhoria da sustentabilidade ao longo do tempo nas lavouras de café. Para isso, foi realizado um estudo de caso com duas propriedades no sul do estado de Minas Gerais, em que uma delas não buscou a melhoria contínua, enquanto a outra buscou. No primeiro caso de estudo foi observado que a fazenda reduziu o número de exigências solicitadas pelo programa de certificação ao longo do tempo. Enquanto no segundo caso a fazenda sofreu uma redução no investimento e demonstrou pouca preocupação em manter os requisitos estabelecidos pela certificação. Por fim, este artigo supõe que a melhoria da sustentabilidade depende do entendimento dos benefícios da certificação em longo prazo e está relacionada a uma mudança de comportamento da fazenda certificada.

Termos para indexação: Certifica Minas Café, melhoria da sustentabilidade, produção cafeeira.

\section{INTRODUCTION}

In 2006, the Government of the State of Minas Gerais established a certification program for coffee plantations, which stands out as the only one proposed and administered by the Government. Although, there are at least ten other certifications in Brazil for the coffee market, all of them of private character, such as the Rainforest Alliance, Organic, Nespresso AAA, 4C (Community Code Commonwealth), UTZ Certified, Fair Trade, Globalgap, Starbucks CAFE Practices and Brazilian Specialty Coffee Association.

This work had access to certification audit reports of a total of 1,347 properties that were certified in the criteria established by the Certifica Minas Café program, with all the scores awarded to each property, from the first year of certification until the year 2015. The examination of the material reveals that, comparing the scores from the first year of certification and from 2015, a total of 337 properties had a decrease in the scores obtained; another 80 properties kept the same scores and 930 properties have increased scores since the first year of entry into the program. In the light of these preliminary data, two fundamental questions emerge: Why do some rural properties in certification, over the years, improve their socio-environmental performance, while other properties have a worsening of these same results? What factors may be contributing to positive or negative certification performance? These were the central questions that this study sought to answer.

1,2,3,4 Universidade Federal de Alfenas/UNIFAL - Instituto de Ciências Exatas/ICEX Cx.P. 3037- 37.130-001 - Alfenas - MG claudio@vieiracastro.com.br,jmslira1283@gmail.com, eduardosalgado@bcc.unifal-mg.edu, luiz.beijo@unifal-mg.edu.br

Coffee Science, Lavras, v. 13, n. 4, p. 539 - 549, oct./dec. 2018 
The Certifica Minas Café regulations provide that the program is intended to establish a certification system for coffee plantations in the State of Minas Gerais that can be applied to all properties, regardless of location or possible differences in technology standards applied to productive processes (CASTRO; SALGADO; BEIJO, 2017). The proposal is to establish their own certification, with an independent verification system, but at the same time allowing the exchange of technologies and regulations with national and international entities related to certification of coffee, in order to encourage the adoption of good agricultural practices in the production, contributing to the safety and reliability of the coffee produced in the State (MINAS, 2009).

Upon entering the program, the rural property is able to adjust from an initial assessment made on the basis of specific requirements and through the monitoring of a technical staff provided by the State itself. Since the beginning of the program, certification requirements have been modified, added or suppressed, adapting to the parameters desired by the managing bodies. The intention evidenced through the evolution of the requirements is to promote a gradual resurgence of certification requirements, aiming to reach the desired quality standards, through a process of raising producers' awareness about the need to adapt and improve the coffee production activity. In the version adopted from 2016, there are 102 requirements:

a) 26 requirements considered mandatory, evaluated with weight 3 , whose non-compliance results in non-certification of the property;

b) 55 restrictive requirements, evaluated with weight 2 , whose non-compliance does not compromise the achievement or continuity of certification; and

c) 21 recommended requirements, where certification occurs, regardless of compliance, but they are evaluated with weight 1 (MINAS, 2016a).

The criterion "Plantation" includes requirements related to propagation material, cultivation areas, pest and disease control, irrigation, and also requirements related to techniques adopted at harvest and post-harvest. In this criterion, appropriate conditions are required for coffee seedlings, field identification of the soil, soil fertility assessment, laboratory analysis for liming and fertilization recommendations, use of agrochemicals in accordance with prescriptions and technical recommendations, use of personal protection equipment, appropriate storage and disposal of packaging, records, training and grants for irrigation activities.
In the "Traceability" criterion, the aim is to record all stages of production, from the planting, harvesting, post-harvesting, storage and marketing of the coffee produced. Records need to be sufficient to identify the origin of the coffee, separating certified coffees from others that may be produced on the property.

The criterion of "Environmental Responsibility", presents requirements related to compliance with environmental legislation, soil conservation and management of weeds (brushcutting, manual weeding, chemical control, among others), water, air (deforestation, fires), biodiversity (trade in wild fauna and flora species) and the appropriate disposal of waste generated on the property (including domestic sewage) and those residues resulting from agro-industrial and agricultural activities. The highlight is the requirements related to water conservation, with $37.03 \%$ of the total, requiring identification of springs that may exist in the property, adoption of protection practices for springs and measures to protect the areas considered as recharge (hill tops), prohibition of interventions in watercourses without the authorization of the competent bodies, re-use of the water from post-harvest processes and the proper disposal of wastewater from the washing or processing of coffee. Certification also intends to make the producer aware of the need to adopt water preservation and conservation measures.

In turn, the "Social Responsibility" criterion addresses requirements related to labour and health and occupational safety aspects, in a context where child labour, forced labour, and discriminatory practices of any kind and related to trafficking of people are strictly prohibited, and must be "excluded from and banished from the property" (MINAS, 2016a). In addition, certification aims to deal with the regularization of labour activities (registration of employees), appropriate transport, appropriate eating areas, appropriate sanitary facilities and access to health systems, identification of risk areas, adoption of internal commissions for the prevention of accidents (where applicable), periodic medical examinations. Certification also includes the adoption of measures, such as taking care of containers that can accumulate water, to prevent the occurrence of the Aedes aegypti (Linnaeus, 1762) mosquito, associated with diseases such as the dengue fever. 
On the other hand, the criterion "Training" has requirements related to the training of workers. These trainings are associated with work safety, pest and disease management, application of agrochemicals and operation of production equipment, such as tractors, harvesters, brush cutters, coffee stripping machines and chainsaws. It also includes the training of workers in the preparation, harvesting, drying, storage and processing of coffee.

Finally, certification presents the criterion called "Property Management", with only two requirements: the first one related to production cost control, where it is expected that the producer can annually evaluate the profitability of at least one field or tract of land; and the second requirement refers to the adoption of a methodology that allows the producer to handle complaints from interested parties if he develops the roasting activity and has his own brand of the coffee produced.

After the training period, the property is submitted to the certification audit, being obliged to meet $100 \%$ of the mandatory requirements and overall to at least $80 \%$ of the total requirements. If the property is disapproved, it can take corrective actions to obtain or maintain certification, which will only be cancelled in the event of not taking the required corrective actions. When the requirement is considered as compliant or noncompliant, it receives a score of 1 or zero and may be considered as not applicable. There is the possibility of imposing suspension penalties and even cancellation of certification, if producers fail to comply with the contractual rules, spread the word that the coffee produced has characteristics not included in the certification, such as informing that the coffee is organic, using the seals in uncertified coffees or the use of counterfeit seals or if contaminations are found in certified coffees (Empresa de Assistência Técnica e Extensão Rural do Estado de Minas Gerais - EMATER, 2011). Certification maintenance audits are conducted annually at all properties participating in the program on previously scheduled visits.

\section{MATERIALS AND METHODS}

In order to respond to the inquiries of this work, the case study methodology was adopted, because it is appropriate for the intended scope, since it allows investigating a contemporary phenomenon under such conditions where, in the definition of Yin (2015) Figure 1 illustrates the steps that were implemented in the present study:

Based on the finding of differences in socioenvironmental performance among properties in the Certifica Minas Café, the research sought to identify two rural properties that were located in nearby geographic areas, with similar planting and productivity areas. One of the properties should show increasing performance, and the other, a decreasing performance, from the first year of certification. Once grouped according to these characteristics, the cases were chosen by drawings of lot. The proposal was to make a more homogeneous choice, avoiding that the differentiation factors of the properties, such as their location, size and technological standard of production could interfere in a relevant way in the performance analyses.

The research protocol involved conducting a semi-structured interview with the property manager (or the owner), based on a predefined questionnaire and analysis of the available audit reports on the property. The protocol was approved by the Ethics Committee (CAAE 50770215.0.0000.5142), and the interviews were submitted to terms of consent and authorization for the recording of voice and images.

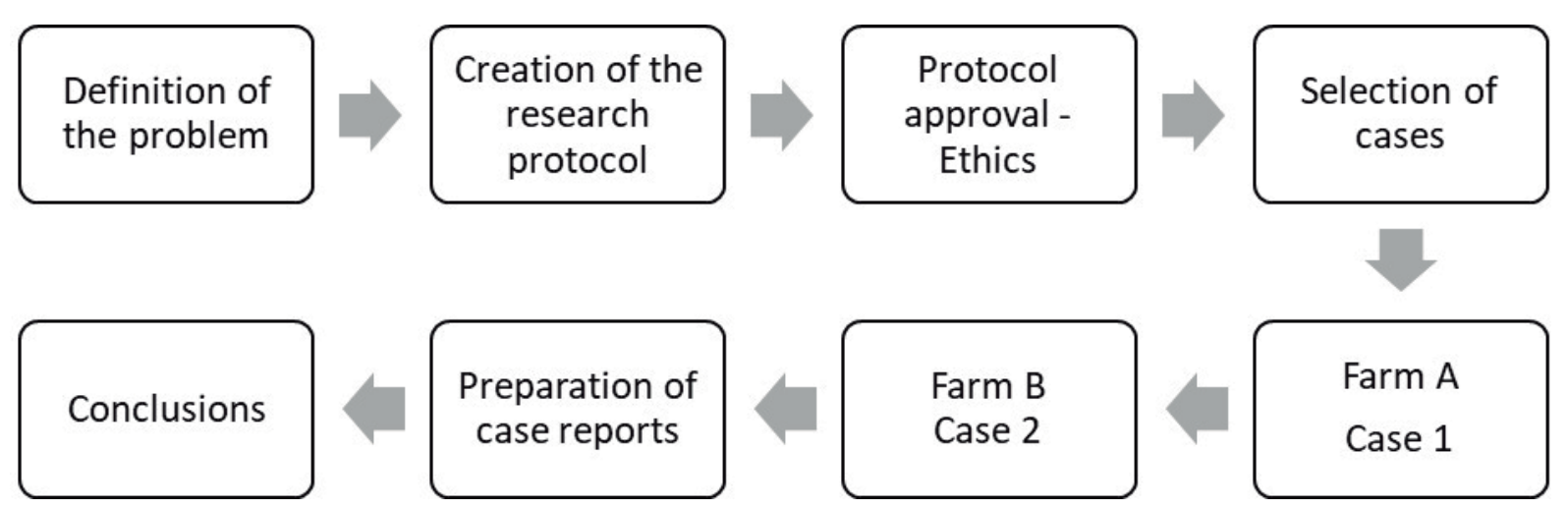

FIGURE 1 - Flowchart of the case study. Prepared by the authors, adapted from Yin (2015). 
The study procedure provided for the maintenance by the authors of the strict confidentiality of personal data of participants and also of the data that could identify the rural properties involved, even in the hypotheses of publication of the data in specialized scientific journals. Because of this, in this study the chosen properties were identified as Farm A (did not continuous improvement) and Farm B (continuous improvement). The interviews and visits to the property occurred between the months of May and December 2016.

\section{RESULTS AND DISCUSSION}

Farm A was visited during the coffee harvest, at the beginning of May, 2016. The property started the certification process in 2012 and was certified for the first time in 2013. The farm has $60.6 \%$ of the property with coffee plantations, with an average yield of 37.78 bags per hectare. The property manager, who has been employed for 26 years and directly responsible for certification since its implementation, was interviewed.

Our study had access to scores obtained by Farm A, from 2013 to 2015. Figure 2 below indicates the reduction of socio-environmental performance of the property, based on the certification requirements.

In addition to the scores obtained in the certification, two audit reports on Farm A were analysed, the first in $2013,98.3 \%$ of the requirements, and the second in $2015,94.8 \%$ of the requirements. Table 1 below presents only those requirements that have changed, with the exception of item 5, in the assessment for the years indicated.

Thus, based on the percentages of compliance with the certification requirements, Farm A, over time, had a deterioration in its socioenvironmental performance.

Items $1,3,4,6$ and 8 of Table 2 were responsible for the reduction in the score obtained in 2015, when compared to that obtained in 2013. Items 2 and 7 revealed improvements, but not enough to prevent a decline in property performance. In item 5, there was a negative evaluation (noncompliance of the requirement) for the entire period considered. The property manager was asked to explain each of the items mentioned.

Regarding item 1, the manager clarified that the negative evaluation occurred due to the time at which the audit was performed. In 2015, they have been audited at the beginning of the harvest, when they started harvesting with more green grains, "to avoid sweating coffee", but that this criterion was met at the end of the harvest, although the information was not evidenced. It was explained as a change of strategy used in recent years. However, the certification requirement is related to the beginning of the harvest and not to the end as clarified by the manager, who associated the practice to a greater use of the fruits, with reduction of the sweeping coffees. Certification allows a maximum of $30 \%$ of green grains, considered unripe because these grains do not have a balanced chemical composition, as they have not yet fully developed, which compromises the full development of the organoleptic properties of coffee and gives rise to drinks that are "harsh, astringent and with marked bitterness "and therefore with inferior quality to that drink prepared with ripe grains (GIOMO, 2012). Although not expressly stated by the manager, the practice of harvesting green beans indicates the preference for a quantitative harvesting of the crop, to the detriment of the qualitative aspect of the coffee produced.

The analysis of the presence of faecal coliforms in the water used in the post-harvest process (item 2) was an improvement evidenced by the audit carried out in 2015, after being designated as non-compliance in 2013. According to the manager, the activity was performed by a company specially hired for this purpose and the point highlighted in the interview was the additional cost of this hiring.

The cleaning of the facilities for processing and storage of the coffee beans before reuse (item 3 ) was not evidenced. According to the manager, it was just a case of forgetting about the requirement of recording the activity:

[...] It was not registered because we forgot. We did, but we did not record. We used to do the cleanings, but we did not have to record. We still do the cleaning, but we miss some details, because of the rush. We did not have an Internal Accident Prevention Committee (CIPA) set up yet, and there was only me and the crop supervisor. Today we have the workplace safety technician, who has the responsibility of making these records.

The same explanation was given for noncompliance with item 4. Farm A failed to renewal the environmental permit after its expiration, although the procedure is not considered by the manager as difficult to carry out. When questioned about the item, the manager replied that it is not complicated to renew the permit, "but we did not do it for lack of time", drawing a brief smile, denoting a certain embarrassment for the lack of a plausible explanation for not performing an activity required by certification. 


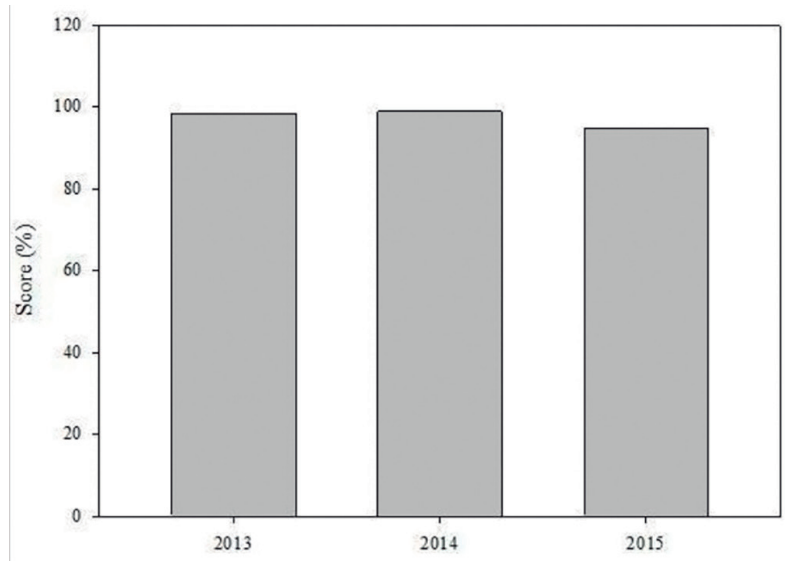

FIGURE 2 - Graphic of Annual scores obtained by Farm A, verified in the certification audits. Source: IMA MG.

TABLE 1 - Farm A. Requirements with changes in the audits performed in 2013 and 2015

\begin{tabular}{|c|c|c|c|}
\hline Item & Requirement & 2013 & 2015 \\
\hline 1 & Harvesting should start when there is the least amount of green grains & $\mathbf{X}$ & \\
\hline 2 & $\begin{array}{l}\text { The inlet water in post-harvest processes should meet minimum faecal } \\
\text { coliform standards }\end{array}$ & & $\mathbf{X}$ \\
\hline 3 & Processing and storage facilities must be sanitized before reuse & $\mathbf{X}$ & \\
\hline 4 & $\begin{array}{l}\text { The property must prove the existence of a permit or environmental } \\
\text { authorization or a certificate of exemption from licensing }\end{array}$ & $\mathbf{X}$ & \\
\hline 5 & Household waste must have appropriate treatment (use of septic tanks) & & \\
\hline 6 & Implementation of work safety training & $\mathbf{X}$ & \\
\hline 7 & Training of manual trimmers operators & & $\mathbf{X}$ \\
\hline 8 & Training of chainsaw operators & NA & \\
\hline
\end{tabular}

The requirement for the treatment of domestic sewage (item 5) through the use of septic tanks or other recommended treatments (digester, filters, among others) remains a problem in Farm A since the beginning of certification. The inappropriate disposal of domestic sewage occurs in most coffee farms, according to Araujo et al., (2016), in a research on the socio-environmental impacts of certifications in cooperatives of family producers in the states of Minas Gerais and Espírito Santo. In most cases, domestic sewage is taken to cesspools, "when not directly to watercourses," the authors point out. Farm A manager is fully aware of the requirement and the need for its implementation, but has not yet been able to allocate the financial resources required to execute the service. Farm A has 17 houses used by its employees and none of them has a septic tank.
We still do not have the septic tank, we have not done it yet. This makes it expensive, because of the construction, but we have not done it yet because of the time, which did not let us do. There is a lot of stone in the colony [referring to the place of residence of employees] and this makes it difficult to execute. The ones they have there are very shallow, but the boss has decided that he will do it. The Certifica Minas Café staff has been asking us for these tanks in all their visits. The boss is who decides when to do it. He said he will do it, but the time is passing and we are doing other things.

Items 6,7 and 8 are all associated with worker training. Farm A stopped practicing work safety training, between 2013 and 2015 it carried out the training for the use of brush cutters and did 
not carry out the training for the use of chainsaws in 2015, and in this item, in 2013 there was no the equipment on the property and therefore the evaluation was considered not applicable in that year. The manager explained that in the case of using chainsaws, a minimum of 8 participants is required for the training, but the farm has only two employees assigned to these activities and therefore did not do so, also claiming that the distance from the training has made the participation of employees impossible. Previous research has pointed out advances in the aspects related to the training of workers in certified farms, although the numbers are still inexpressive, pointing out irregularities in $55 \%$ of the properties certified by the Certifica Minas Café (SANTOS et al., 2015).

When asked to reflect on the impact of certification on the property, Farm A manager reported that Certifica Minas Café brought good results and improvements for employees, but that certification did not add value to the price of certified coffee, although the comparison of prices can reveal incorrect data, given the differences in demand between certified and non-certified coffees, as Barham and Weber (2012) have pointed out. The manager recognizes that several practices with the crop were only implemented in the property after certification, such as the appropriate programming and the technical recommendation for the application of agrochemicals. The traceability of coffee, in the manager's view, was a beneficial measure brought about by certification. But the focus of his analysis is geared especially to the final price aspect of certified coffee:

The boss says that so far it has not brought improvement in price. We'll have to get certified because everyone is doing it, but it needed to add value from $5 \%$ to $10 \%$, which he commented to the bank staff a few days ago. He will continue, but it needed to add value. This gives a certain discouragement, because we spend more, we have to hire personnel, but it has no financial return.

[...] some things we leave behind because it does not have much importance, like a simple annotation, for example. Then we do the things that are more important.

The manager's explanation makes it clear that there is a selective attitude to the measures recommended by certification that will or will not be implemented in the property. The cost of the measures to be adopted is a relevant factor, but it is not the only one, because as presented in the results presented some simple measures are no longer adopted because they have been forgotten or were not considered important by those who have the obligation to adopt the requirements of certification.

Farm B was visited during the off-season, at the end of November 2016. It began preparations for certification in 2009 and was certified for the first time in 2010. It occupies 56\% of the area of the property with coffee plantations, with an average yield of 30 sacks per hectare. The interview was held at the property's headquarters with one of the partners, who is directly responsible for managing the certification.

Unlike the previous case, Farm B actively disseminates property certification, from the entrance gate to the various production and processing areas. The owner acquired the farm 10 years ago, when he began planting the first lands, with the purpose of making the property a model in the production of coffee. He has brought a business vision to management, results oriented, to achieve productivity, profitability and socio-environmental sustainability. In this sense, the owner understands that the implementation of certification was a very important dividing point for the management of the processes, improvement of the productive base and the quality of the coffee produced, being able to add all these aspects to the products and the people involved. The economic aspect related to the price of coffee is seen in another way:

[...] We were able to generate value to our business, to our product. So, I'm sure certification is not what you get on certified products, that's what's left over, because a certified property has a very efficient management ... and I felt it improved a lot, not only my life but the lives of those who work with me.

When asked to explain the gains from certification, the owner can list a number of topics by dividing them into environmental, social and economic aspects. In the first aspect, he points out that certification brought environmental licensing, the construction of septic tanks, the appropriate disposal of waste, the reuse of coffee straw in fertilization and the reutilization of wastewaters from the coffee washing in composting, with the use of bacteria. In the social aspect, the highlight is the intensive training of permanent employees (the property has four employees) and of those who are hired during the harvests (from 10 to 20 employees, depending on the harvest), emphasizing that investments in training and qualification are indispensable, since "You 
do not make a special coffee without special people". And in the economic aspect, the owner emphasizes that certification adds value to the business, even allowing the export of the product, but understands that it is not the certification that ensures better prices, but the quality of the final product. Therefore, what drives the owner to stay certified is not the immediate economic result, but the combination of environmental, social and economic aspects. The view of the owner of Farm $\mathrm{B}$ contrasts with other works where the economic aspect was pointed out as the main driver of certification, being this the determining factor of the continuity of the producer in the programs, as Ibnu et al. (2015) stated when researching certified and non-certified coffee producers in Indonesia. From an economic perspective, the owner of Farm B explained his view as follows:

"What opens doors is not the Certifica Minas Café, but quality. When coffee has quality and is certified, then the producer is able to sell it for a higher price. Anyone who sees otherwise has difficulties and becomes less involved with certification. And when the producer has this resistance, he loses even the opportunity to open doors to other markets, he loses opportunities."

For Farm B, the improvement of production processes, involving crop planning, the abandonment of practices that may compromise quality, such as the use of sweeping coffee and the cultivation of organic matter in the soil are also relevant, as they provide what is defined as "the emergence of a microclimate" in agriculture, which impacts the quality and sustainability of the business. To a certain extent, it is the same as mentioned by Leme and Gandia (2013) that have proposed an explanatory model for the analysis of the market for certified and special coffees and pointed to other benefits deriving from certification, besides price, such as the organization of work, which results in the greater control of the producer to his production system, with consequences in reducing costs and improving the quality of the final product. The owner of Farm B understands that all these benefits cited by Leme and Gandia (2013) are aggregated by certification and in a simple and direct way explains the partnership relationship that develops between the certifier and the property:

"Certification brings this vision. When you are not certified, you do not have this vision. It's as if you have a person, someone to whom you are subordinated to and have to render account. It is a partnership relationship, because our results are theirs too. I celebrate all my scores. This year, we almost scored 10. We fell short ... "“

The Research had access to the 2013 and 2015 reports of Farm B and access to the scores obtained from the first year of certification until 2016, when Farm B was visited. The data reflects the long-term vision of the enterprise. In seeking to achieve a sustainable productive arrangement, the results are gradually being incorporated into the business. The owner is aware that the major changes are behavioural.

Therefore, the challenge is precisely to make these changes in the way of producing be able to modify the behaviour of managers and employees, becoming routine in the business. Figure 3 below shows the clear improvement of property performance in the requirements, when observed all the certification time.

The changes indicated in the audit reports for 2013 and 2015 were consolidated in Table 2.

For the owner of Farm B, all nonconformities identified in certifications resulted in opportunities for improvement and were important to raise awareness of the need to be implemented and this implies changes in behaviour. For example, the use of personal protective equipment (PPE) where "employees do not like to use it, they feel uncomfortable, but they must be aware that it is important to use it for their safety". Therefore, he explained that some of the nonconformities occurred only after the certification audits warned about the need for improvements, not only because of the scores, but especially because of the results that these improvements have on quality of life, as occurred with the treatment of household waste (item 3) non-compliance indicated in 2013 and corrected in the audit of 2015. Weighing on the importance of certification to improve the quality of life of producers and communities is in harmony with the results obtained by Rueda and Lambin (2013) when assessing the potential of certification in Colombia to promote socioecological systems more resistant to the processes of globalization. The owner of Farm B explains his view as follows:

"That was an adjustment we had to make. First, we did at our employee's house because he lives there permanently. Then we did at the farm headquarters. It demanded time and logistics, more than cost. [...] If the producer understood that he is the one who gets the improvement, it would be much easier and he would be much more evolved in the certification processes. " 


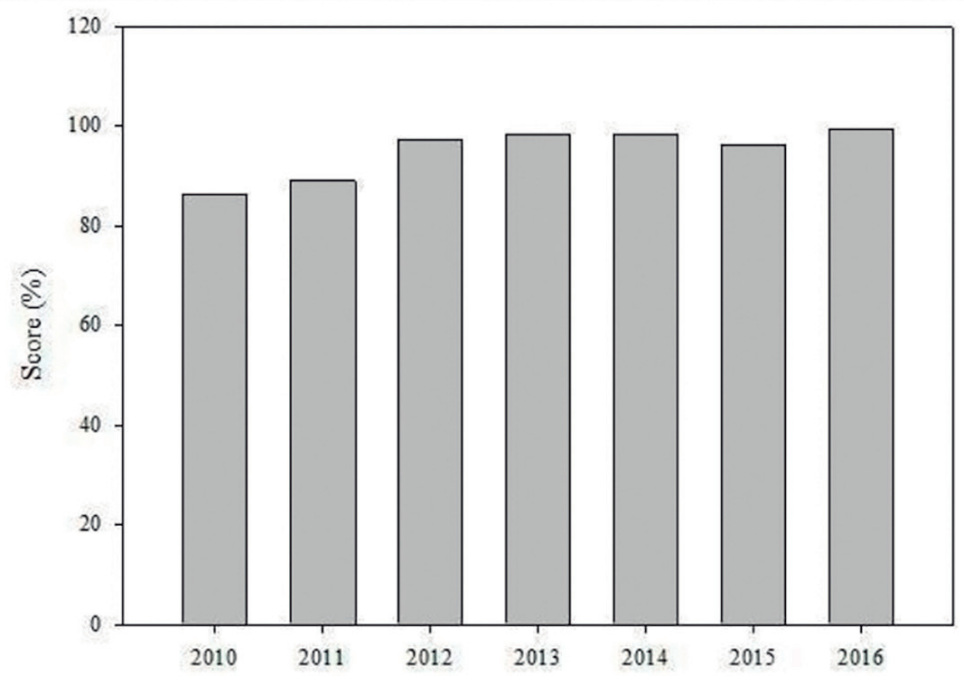

FIGURE 3 - Annual scores obtained by Farm B, verified in the certification audits.

TABLE 2 - Farm B. Requirements with changes. Audits carried out in 2013 and 2015.

\begin{tabular}{clcc}
\hline Item & Requirement & $\mathbf{2 0 1 3}$ & $\mathbf{2 0 1 5}$ \\
\hline 1 & Harvesting should start when there is the least amount of green grains & $\mathbf{X}$ & \\
2 & $\begin{array}{l}\text { The inlet water in post-harvest processes should meet minimum faecal } \\
\text { coliform standards }\end{array}$ & $\mathbf{X}$ & \\
3 & Household waste must have appropriate treatment (use of septic tanks) & & $\mathbf{X}$ \\
4 & Implementation of work safety training & \\
\hline 5 & Training in the integrated management of pests and diseases & \\
\hline
\end{tabular}

Requirement completed is marked with X, Requirement not completed is empty and Not applicable (NA)

The problem of the records is a major challenge to certification, according to the owner of Farm B, especially the record of activities that, prior to certification, were already routine in the management of the property, such as fertilization. The challenge, therefore, is to incorporate the requirements added by certification into the already established culture. This observation corroborates the results found by Vriesman et al. (2012), which, in the consolidation of 149 case studies involving technical assistance for the certification of organic products from family agriculture, pointed out the records as the main difficulty for producers. Therefore, among the processes implemented in Farm B is carrying out activities through work orders. All employees leave for farming with written work orders that were previously planned.
At the end of the day, they return with the orders filled out, informing what was done. The owner clarifies: "Our mission is to interpret these data and turn them into decisions," which takes time for this new culture to be fully absorbed by those involved.

The training activities, whether in work safety (item 4) or in the integrated management of pests and diseases (item 5) were carried out, reported the owner, but the evidence of its realization was lacking. Regarding item 5, the fault was attributed to service providers, who would have been hired specifically for this activity. In the view of the audit finding, the owner considered the possibility of termination of the outsourcing of those services, in the event of persistence of implementation flaws. What the owner wanted to 
emphasize was that behavioural change should affect not only the internal environment of the property (managers and workers) but that it should also extend to the contracted service providers, who should be guided on the importance of meeting the certification requirements

Regarding items 1 and 2, the owner was not able to answer what happened in the specific case, but he informed and presented the audit report where it was stated that the only non-compliance in 2016 was again the lack of evidence of training in the management of pests and diseases (item 5) and because of this item, it was considered that the property met $99.4 \%$ of all requirements of the standard.

"As we get involved in all activities, all without exception, we end up forgetting to ask for some items. So Itold him [referring to the contracted technician for pest and disease management] that if he does not do it as required, he cannot stay with me because I cannot do everything. If he doesn't do it, I'll have to replace him. "

The last question of the interview with the owner of Farm B was related to the future of the property and the coffee industry itself, since he understands that certification is a "no-return path", and anyone who takes time to understand this may have difficulties in the future to reach those who came out first. And who is focused only on the immediate financial results, according to his vision, has not yet understood how to achieve higher prices for coffee produced, as pointed out in previous studies that verified the percentage of $60 \%$ of owners of certified coffee farms that understand certification as a necessity for the future and not for the present (BÓCOLI et al., 2013). The owner of Farm B explains his view as follows:

"The world is looking for quality coffees. The consumption of quality coffees is increasing. We are the only country in the world that can meet world demand for quality coffees. We have a market full of opportunities. We have many challenges too, such as climate change that are very cruel. So if we do not start doing differently, producing sustainably, we will have great difficulties ahead. We have to start now: in the choice of products, in the productive arrangements, and to know how to use all that we do as competitive advantages of our coffees. And this coffee will be worth much more. "
From the data obtained in this research it is possible to affirm that there is a distinct difference in the certified rural properties performance in terms of meeting the requirements required by certification. Table 3 illustrates the main points that were evidenced in this work regarding the differences found in the comparison of Farms A and $\mathrm{B}$.

What is observed in the cases studied was that Farm A faces accommodation in meeting the criteria, while Farm B has presented a continuous improvement in its evaluations. The case study allows us to hypothesize that these differences are directly associated with the degree of owner's commitment to certification.

In Farm A, the focus is on the immediate results that certification can bring, notably on the impact on the final price of the product. The expectation is that certification could result in an increase in the price of coffee marketed. On the other hand, the owner of Farm B understands certification as a process, whose objectives are achieved in the long run. Thus, it does not expect an immediate economic result that can positively impact the price of its product, but understands certification as an ally in obtaining better quality coffees, which is responsible for the increase in market prices (MAEKAWA, CARVALHO; OLIVEIRA, 2013; PEREIRA et al., 2013; MARTINS; SILVA, 2014). Thus, in the face of the finding that occurs after some time of permanence in the program that these results may not happen with this logic, there is a process of accommodation and sometimes resistance in realizing the investments that certification may require, which in extreme cases leads to even the abandonment of the program. This work also contributes to the debate on the continuity of certifications, allowing management agencies to plan the activities of publicity and awareness of the target audience.

In addition to the limitations of the adopted methodology, it should be noted that, although the farms studied are in the same geographic region and have similarities in size and productivity, there is a difference of time in which they are certified. Farm A has 4 years of certification, while Farm B is in the seventh year, and it is possible to assume that this factor may in some way interfere in the degree of maturity and consequently in the results of certification. Future work may include the analysis of the time of certification factor in the performance of certified properties. 
TABLE 3 - Criteria for analysis and differences in the socio-environmental performance of farms.

\begin{tabular}{lcc}
\hline Criteria for analysis & Farm A & Farm B \\
\hline Improvement in score in the program & No & Yes \\
Meeting certification requirements & Accommodation & Improvement \\
Investments in the program & Restrictive & Substantial \\
Results expected & Short term & Long term \\
Expectation of better coffee prices & Yes & No \\
Understanding of certification & Distortions & Yes \\
\hline
\end{tabular}

\section{CONCLUSIONS}

The certifications and management systems benefits is closely related to a behavioural change of the organization, involving motivation, improvement of image and production processes, increase of satisfaction, worker involvement, with direct impact on customer service by offering quality products. However, Certifica Minas Café can lead to improved sustainability of coffee farms in the long term, but the maintenance of the requirements established by the certificate is still low, which makes it difficult to observe sustainability improvements in the future. In this way, the constant technical monitoring for the farmers is fundamental for the effect of the certifications improvements.

\section{REFERENCES}

ARAÚJO, G. J. F. de.; MAGALHÃES, D.; GOMES, E. T. A. Impactos socioambientais da certificação fairtrade nas cooperativas de produtores familiares de café e manga no Brasil. Confins, São Paulo, v. 10, n. 29, Dec. 2016.

AMARAL, A. M. S. do. et al. Influência do certifica minas café nas lavouras cafeeiras de alfenas, sul de minas gerais. Coffee Science, Lavras, v. 12, n. 1, p. 114-123, Jan./Mar. 2017.

BARHAM, B. L.; WEBER, J. G. The Economic Sustainability of Certified Coffee: Recent Evidence from Mexico and Peru. World Development, v. 40, n. 6, p. 1269-1279, June. 2012.

BÓCOLI, C. I. C. et al. Estudo do perfil de cafeicultores certificados e não certificados. In: VIII SIMPÓSIO DE PESQUISA DOS CAFÉS DO BRASIL, 1., 2013, Salvador. Resumos Expandidos... Brasília: Embrapa Café; p. 6. Available in: <http://www.sapc.embrapa.br/ arquivos/consorcio/spcb_anais/simposio8/243.pdf>.
CASTRO, C. V.; SAlGADO, E. G.; BEIJO, L. A. Certifica Minas Café: A new paradigm of the state in environmental protection? Coffee Science, Lavras, v. 12, n. 4, p. 562-574, Oct./Dec. 2017.

EMATER. Manual do Produtor. Available in: $<$ http:// www.ima.mg.gov.br/portarias/doc_download/1113manual-do-produtor-cafe->. Access on: 26 April 2015.

GIOMO, G. S. Café: uma boa pós-colheita é o segredo da qualidade. A Lavoura, Rio de Janeiro, v. 1, n. 1, p. 12-21, 2012.

IBNU, M. et al. Farmer Preferences for Coffee Certification: A Conjoint Analysis of the Indonesian Smallholders. Journal of Agricultural Science, Toronto, v. 7, n. 6, p. 20, 2015.

LEME, P. H. M. V.; GANDIA, R. M. As certificações como dispositivos de formação de mercados: um ensaio teórico sobre os processos de qualificação e marketização. In: SEMINÁRIOS EM ADMINISTRAÇÃO-SEMEAD, 1, 2013, São Paulo. Resumos Expandidos... São Paulo: USP, p. 1-16. Available in: <http://sistema.semead.com.br/16semead/ resultado/trabalhospdf/667.pdf > .

MAEKAWA, R.; CARVALHO, M. M.; OLIVEIRA, O. J. Um estudo sobre a certificação ISO 9001 no Brasil : mapeamento de motivações, benefícios e dificuldades. Gestão \& Produção, São Carlos, v. 20, n. 4, p. 763779, Oct./Dec. 2013.

MARTINS, M. R. S.; SILVA, J. G. F. O sistema de gestão ambiental baseado na ISO 14000 : Importância do instrumento no caminho da sustentabilidade ambiental. Revista Eletrônica em Gestão, Educação e Tecnologia Ambiental, Santa Maria, v. 18, n. 4, p. 1460-1466, Dec. 2014.

MINAS, G. F. GEC 055 - Normas para certificação. Available in: <http://www.ima.mg.gov.br/materialcurso-cfo-cfoc/doc_details/3064-fgec055-normaspara-certificacao-de-propriedades-cafeeiras- $>$. Access in: 10 Aug. 2016. 
MINAS, G. Certifica Minas Café - Regulamento Geral. Belo Horizonte - MG: Diario Oficial do Estado de Minas Gerais, 2009.

PEREIRA, A. C. et al. Percepções de gestores sobre as contribuições do processo de certifica - ção ISO 14001 nas práticas de gestão ambiental Informações do Artigo. Revista Cantabilidade \& Organizações, São Paulo, v. 7, n. 17, p. 73-88, July. 2013.

RUEDA, X.; LAMBIN, E. F. Responding to globalization: Impacts of certification on Colombian small-scale coffee growers. Ecology and Society, Nova Scotia, v. 18, n. 3, p. 1-21, 2013.
SANTOS, J. C. F. et al. Comparativo de Conformidades de Cafeicultores do Cerrado sobre Normas de Programas de Certificação. Revista Saúde e Meio Ambiente, v. 4, n. 1, p. 127-146, 2015.

SOUZA, S. M. C. et al. Avaliação de grau de conformidade visando à inserção dos cafeicultores na certificação e comercio justo (Fair Trade). Coffee Science, Lavras, v. 8, n. 4, p. 510-518, Oct./Dec. 2013

VRIESMAN, A. K. et al. Assistência técnica e extensão rural para a certificação de produtos orgânicos da agricultura familiar. Conexão UEPG, Ponta Grossa, v. 8, n. 1, p. 138-149, Jan./June. 2012.

YIN, R. K. Estudo de Caso: Planejamento e métodos. $5^{\mathrm{a}}$ ed. São Paulo, SP: Bookman Companhia Editora, 2015. 